\title{
Konsep Pendidikan Ibnu Sina tentang Tujuan Pendidikan, Kurikulum, Metode Pembelajaran, dan Guru
}

\author{
Idris Rasyid ${ }^{1}$ * \\ ${ }^{1}$ Program Studi Pendidikan Agama Islam, Institut Agama Islam Negeri Bone, Jl. HOS. Cokroaminoto, \\ Kabupaten Bone, Sulawesi Selatan, Indonesia. \\ * Korespondensi Penulis. E-mail: idrisrasyid@gmail.com
}

\begin{abstract}
Abstrak
Ibnu Sina atau Evicienna adalah merupakan salah satu tokoh yang memiliki kontribusi besar dalam khazanah keilmuan dalam Islam khususnya yang berkaitan dengan pendidikan Islam. Disamping itu, pemikiran Ibnu Sina mengenai pendidikan secara terstruktur dari tujuan, kurikulum, metode pembelajaran dan guru atau pendidik ialah faktron daripada unsur-usur determinan dalam pendidikan. Oleh karena itu, pemikiran Ibnu Sina dapat dijadikan acuan penting dalam memajukan dunia pendidikan. Dalam pandangan lain, bahwa hasil pemikiran Ibnu Sina tidak lain merupakan pengalaman hidupnya dalam menemukan ilmu pengetahuan yang sangat luas kemudian dituangkan kedalam media tulis dan menjadi sumber primer ilmu pengetahuan pada masanya. Dalam kaitan ini, kajian yang telah dipaparkan adalah salah satu asumsi menggali sumber primer tersebut dari khazanah keilmuan Ibnu Sina.
\end{abstract}

Kata Kunci: Konsep Pendidikan, Ibnu Sina, Evicienna, Metode Pembelajaran, Guru, Kurikulum

\section{Ibn Sina's Educational Concept of Educational Objectives, Curriculum, Learning Methods, and Teachers}

\begin{abstract}
Ibnu Sina or Evicienna is one of the figures who has a major contribution in the treasures of science in Islam, especially those related to Islamic education. Besides that, Ibn Sina's thinking about education in a structured manner from goals, curriculum, learning methods and teachers or educators is factron rather than determinant elements in education. Therefore, the thought of Ibn Sina can be used as an important reference in advancing the world of education. In another view, that the results of Ibn Sina's thoughts were nothing but his life experience in discovering vast knowledge and then poured into written media and became the primary source of knowledge in his time. In this connection, the study that has been presented is one of the assumptions of exploring these primary sources from Ibn Sina's scientific treasures.
\end{abstract}

Keywords: The Concept of Education, Ibn Sina, Evicienna, Learning Methods, Teachers, Curriculum 


\section{PENDAHULUAN}

Huston Smith pernah menyatakan penyesalannya dan merasakan adanya sesuatu yang hilang dalam rangka keberilmuan orang-orang modern masa kini. Ia merasakan tidak terpatrinya pandangan orang moderen dan hasil temuannya dengan Maha Penciptanya. Bukanlah siapa-siapa menemukan sesuatu, tetapi manusia kehilangan sesuatu, karena telah membiarkan diri mereka secara sengaja dan atau tidak sengaja terperangkap dalam epistemologi yang tidak memberikan ruang pada ketuhanan dan pengakuan akan adanya kehidupan di balik kehidupan di dunia ini. ${ }^{1}$ Pendidikan merupakan salah satu kunci yang sangat esensial dalam kehidupan manusia. Dalam konteks dan ruang lingkup kehidupan suatu bangsa, pendidikan memiliki peranan yang sangat penting dan strategis untuk menjamin kelangsungan dan perkembangan kehidupan bangsa tersebut. Karena dari dan dengan pendidikanlah seluruh aspek kehidupan manusia dapat tercerahkan. Pendidikan harus dapat menyiapkan warga negara untuk menghadapi masa depannya. ${ }^{2}$

Idealnya pendidikan mampu menghasilkan pribadi-pribadi yang lebih manusiawi, berdaya guna dan mempunyai pengaruh di dalam masyarakatnya, juga dapat bertanggung jawab atas hidupnya sendiri dan orang lain, yang tentunya dilengkapi dengan watak yang luhur dan berkeahlian. Meminjam pernyataan Immanuel Kant, ${ }^{3}$ yang mengatakan bahwa "manusia hanya dapat menjadi manusia karena pendidikan", dapatlah dipahami bahwa jika manusia itu tidak di didik, maka ia tidak akan dapat menjadi manusia dalam arti yang sebenarnya. Dengan demikian, pendidikan pada dasarnya memberikan pengalaman belajar untuk dapat mengembangkan seluruh potensi yang dimiliki siswa, melalui proses interaksi baik antara siswa dengan siswa, siswa dengan guru, atau siswa dengan lingkungan.

Dunia pendidikan di Indonesia saat ini terlalu asyik membicarakan hasil-hasil temuan, ujicoba (eksperimen), metodelogi, alat-alat pembelajaran yang canggih dan lain-lain sebagainya, sehingga hampir tidak ada waktu untuk memikirkan tujuan akhir dari sebuah proses pendidikan. Kurikulum Pendidikan Sekolah Dasar sampai dengan Perguruan Tinggi direnovasi dan direnovasi terus, bobot mata pelajaran selalu tertambal sulam dengan alasan penyesuaian pendidikan global tanpa memperhitungkan kebobrokan moral peserta didik di masa datang. Kini baru dan mulai disadari, betapa tidak seorang pendidik dicaci maki oleh peserta didiknya, orang tua dibunuh anaknya, dan macam-macam peristiwa yang bermunculan, lalu pemikir-pemikir pendidikan mulai sadar dan mencoba meramu serta memodifikasi sistem dan kurikulum pendidikan yang bernuasa agama, akhlak dan lain-lain untuk mengembalikan objek didik kepada fitrahnya. Seperti Mahmud Yunus mengemukakan tiga alternatif tujuan pendidikan : (1) Untuk mempermudah mencari rezki (kasbu al-rizqi); (2) Untuk memperoleh ilmu pengetahuan (al-ilmu); dan (3) Untuk berprilaku yang baik (akhlak). ${ }^{4}$

Pendidikan Islam merupakan usaha yang menciptakan dan membentuk manusia yang baik dan lebih bermakna dalam kehidupan dunia dan mempersiapkannya untuk kehidupan ukhrawi. Secara konseptual pendidikan Islam diawali oleh landasan - landasan ideologis filosofis untuk pelaksanaannya atau implementasinya pada latar sosial-budaya. Pembaharuan falsafah Islamiyah dalam dunia pendidikan dewasa ini menjadi sangat urgen untuk dilakukan dalam rangka menciptakan pendidikan yang berkualitas seperti yang telah diarahkan oleh kitab suci. ${ }^{5}$ Rekonstruksi falsafah harus dimulai dari aspek ontologis, epistemologi dan axiologi, dalam upaya menjawab tantangan pendidikan Islam saat ini. ${ }^{6}$ Problem adanya dikotomi antara ilmu-ilmu agama dan ilmu umum menyebabkan tidak berkembangnya ilmu pengetahuan dan terjadinya krisis metodologi keilmuan. Krisis yang terjadi dalam dunia pengetahuan dan pendidikan Islam saat ini mengakibatkan tradisi keilmuan menjadi statis, sehingga pendidikan Islam belum menunjukkan perannya secara maksimal dalam menciptakan peradaban yang maju, seperti masa kejayaan Islam pada abad 8-13 M silam. Peradaban Islam tidak lain

${ }^{1}$ Huston Smith and M Darrol Bryant, Essays on World Religion (Paragon House Publishers, 1992).

${ }^{2}$ Saifullah Idris and Z A Tabrani, "Realitas Konsep Pendidikan Humanisme Dalam Konteks Pendidikan Islam,” Jurnal Edukasi: Jurnal Bimbingan Konseling 3, no. 1 (2017): 96-113.

${ }^{3}$ Madyo Eko Susilo and R B Kasihadi, Dasar-Dasar Pendidikan (Semarang: Effhar, 2001).

${ }^{4}$ Mahmud Yunus and Muhammad Qasim Bakri, Al-Tarbiyah Wa Al-Ta'lim (Padang Panjang: Mathba'ah, 1942).

${ }^{5}$ Aris Try Andreas Putra, "Pemikiran Filosofis Pendidikan Ibnu Sina Dan Implikasinya Pada Pendidikan Islam Kontemporer,” LITERASI (Jurnal Ilmu Pendidikan) 6, no. 2 (2016): 191-201.

${ }^{6}$ Putra. 
adalah suatu hasil akumulasi perjalanan pergumulan penganut agama Islam ketika berhadapan dengan proses dialektis antara "normativitas" ajaran wahyu yang permanen dan "historisitas" pengalaman kekhalifaan manusia dimuka bumi yang selalu berubah-ubah. ${ }^{7}$

Untuk melahirkan pendidikan yang berkualitas, harus berangkat pada metodologi pikir yang kuat dan landasan filosofis-epistemologi yang handal. Berdasarkan paradigma humanis-religious harus mempertimbangkan akal sehat, individualism menuju kemandirian, pendidikan pluralis, anti-dikotomi, semangat menggali ilmu yang tulus, fungsionalisme, mengalahkan simbolisme, serta penghargaan dan sanksi. Pendidkan Islam sebagai tujuan, alat perubahan, dan transformasi sosial sudah semestinya diarahkan untuk mengakomodasi budaya lokal dan berorientasi kedapan, yakni yang religious dan modern. ${ }^{8}$

Namun demikian, masih terdapat berbagai persoalan umat dan pendidikan Islam sekarang ini yang menurut Assegaf berpangkal pada pada empat hal sebagai berikut: 1) lemahnya visi (lack vision); 2) penekanan pada kesalehan individual sehingga menyebabkan ketertinggalan teknologi; 3) keilmuan yang dikotomis; dan 4) pola pikir normatif-deduktif. ${ }^{9}$ Keempat hal tersebut harus dicari jalan keluarnya sehingga umat dan pendidikan Islam dapat mengalami perkembangan, kemajuan, dan kejayaan kembali. Dalam hal ini, pemikiran filosofis Ibnu Sina menurut penulis masih sangat relevan untuk diimplementasikan dan mengatasi krisis dan kemandekan dalam pendidikan Islam tersebut. Makanya perlu dilakukan tinjauan reformasi pendidikan baik secara filosofis, epistemologi agar terwujud pendidikan Islam yang sesuai dengan tuntunan wahyu. ${ }^{10}$

Namun demikian, ketika menoleh ke sejarah yang pernah ada peradaban Islam dikenal dipenjuru dunia khususnya mengenai munculnya cendekiawan-cendekiawan yang menguasai ilmu pengetahuan dan filsafat yang mereka pelajari dari bku-buku Yunani. Tetapi menambahkan kedalamnya hasil-hasil penyelidikan yang mereka lakukan sendiri dalam lapangan ilmu pengetahuan mengenai filsafat. Dengan demikian muncullah ahli-ahli ilmu pengetahuan dan filosof Islam. Seperti Al-Fazari astronom Islam, Abu Ali Hasan Ibnu Al-Hatham ahli mata, Jabir Ibnu Hayyan ahli kimia, Abu Raihan Muhammad AlBaituni ahli fisik dan salah satunya bernama Ibnu Sina yang memiliki beberapa keahlian. ${ }^{11}$

Ibnu Sina yang dikenal sebagai seorang filosof dan ahli di bidang kedokteran, akan tetapi beberapa kajian yang dilakukan oleh generasi sesudahnya tentang pemikirannya, ditemukan beberapa pemikirannya tentang konsep pendidikan Islam. Oleh sebab itu, Ibnu Sina juga tercatat sebagai salah satu tokoh pendidikan islam yang memiliki pemikiran yang brilliant. Pemikiran Ibn Sina tentang pendidikan Islam memang telah banyak dikaji oleh para ahli, tetapi tidak berarti kajian tersebut berhenti di situ saja. Pemikiran Ibn Sina yang tertulis dalam karya-karyanya akan tetap relevan untuk dianalisis secara kritis hingga saat ini sehingga menimbulkan dinamika keilmuan yang diharapkan mampu memberikan kontribusi yang bersifat solutif terhadap berbagai permasalahan pendidikan Islam dewasa ini, termasuk di Indonesia. Untuk itu, dalam artikel ini akan mengkaji mengenai pemikiran pendidikan Ibnu Sina baik itu tujuan, kurikulum, metode pembelajaran dan masalah guru.

Oleh karena itu, muslim sejati hendaknya menerjemahkan, dan melaksanakan pendidikan Islam berbasis landasan ontologis, epistemologis dan aksiologis berdasarkan landasan al-qur'an dan as sunah. Seseorang yang mengkaji Islam dari sumbernya al-Qur'an dan al-Hadits dengan kesadaran yang mendalam akan mengeluarkan hasil pikiran yang universal mengenai sesuatu hal, baik filsafat wujud, pengetahuan, dan fi lsafat nilai. Berdasarkan uraian singkat di atas, tentu saja memberikan gambaran singkat yang gradual mengenai rumusan masalahnya. Rumusan masalah yang dimaksud ialah bagaimana konsep pendidikan Ibnu Sina?. Untuk menemukan jawab tersebut, tentu saja dengan mencermati pada dua hal pokok sebagai batasan masalah yaitu: (1) bagaimana sejarah hidup Ibnu Sina?;

${ }^{7}$ Mohd Amin Abdullah, Falsafah Kalam Di Era Postmodernisme (Yogyakarta: Pustaka Pelajar, 1995).

8 Abdurrachman Mas' ud, Menggagas Format Pendidikan Nondikotomik:(Humanisme Religius Sebagai Paradigma Pendidikan Islam) (Gama Media, 2002).

9 Abdur Rahman Assegaf, Filsafat Pendidikan Islam: Paradigma Baru Pendidikan Hadhari Berbasis Integratif-Interkonektif (Rajawali Pers, 2011).

10 Putra, "Pemikiran Filosofis Pendidikan Ibnu Sina Dan Implikasinya Pada Pendidikan Islam Kontemporer."

${ }^{11}$ Harun Nasution, "Islam Ditinjau Dari Berbagai Aspeknya” (UI Press, Cetakan V, 1985). 
dan (2) bagaimana Konsep pendidikan Ibnu Sina mengenai tujuan pendidikan, kurikulum, metode pembelajaran dan guru?.

\section{PEMBAHASAN}

\section{Tentang Ibnu Sina: Lahir Hingga Wafatnya}

Ibnu Sina nama lengkapnya Abu Ali Husain Ibnu Abdullah Ikbn Hasan Ibnu Ali Ibnu Sina. Di barat populer dengan sebutan Avicenna akibat dari terjadinya metamorfosis Yahudi-Spanyol-Latin. Dengan lidah Spanyol kata Ibnu diucapkan Aben atau Even. Terjadinya perubahan ini berawal dari usaha penerjemahan naskah-naskah Arab ke dalam bahasa Latin pada pertengahan abad keduabelas di Spanyol. ${ }^{12}$ Adapula yang berpandangan bahwa nama tersebut diambil dari kata al-shin yang dalam bahasa Arab berarti Cina. Selain itu adapula berpendapat yang mengatakan dihubungkan dengan tempat kelahirannya yaitu Afshana. ${ }^{13}$

Ibnu Sina dilahirkan di Afshana Kabupaten Balkh wilayah Afganistan Propinsi dekat Bukhara pada tahun $370 \mathrm{H} / 980 \mathrm{M}$ dan meninggal pada tahun $1037 \mathrm{M}$ dalam usia 58 Tahun. Jasadnya dikebumikan di Hamdzan. Ibunya bernama Astarah dan ayahnya bernama Abdullah. ${ }^{14}$ Ibnu Sina lahir ditengah masa yang sedang kacau, dimana kekuasaan Abbasiyah mulai mundur dan negeri-negeri yang mula-mula berada dibawah kekuasaannya kini mulai melepaskan diri untuk berdiri sendiri. ${ }^{15}$

Dalam usia mudanya telah menguasai beberapa disiplin ilmu seperti matematika, logika, fisika, kedokteran, astronomi, hukum. Bahkan dalam usia 10 tahun Ibnu Sina telah mengahafal Al-Qur'an. Pada usia 17 tahun sebagai masa geniusnya Ibnu Sina memahami teori kedokteran dan orang sangat mengaguminya. Karena kepintarannya, Ibnu Sina diangkat sebagai konsultan dokter praktisi. Peristiwa ini terjadi ketika Ibnu Sina berhasil mengobati Pangeran Nuh Ibnu Manshur, yang sebelumnya tidak seorang dokter pun mampu menyembuhkannya. Ibnu Sina juga pernah diangkat menjadi menteri oleh Sultan Syams Al-Dawlah berkuasa di Hamdan. ${ }^{16}$

Diantara guru yang mendidiknya ialah Abu Abdullah Al-Natili dan Ismail sang Zahid. Karena kecerdasan otaknya yang luar biasa, Ibnu Sina dapat menguasai semua ilmu yang diajarkan kepadanya dengan sempurna, bahkan melebihi gurunya. Setelah guru-gurunya kewelahan, Ibnu Sina menjadi bingung mencari tempat untuk meuaskan kehausan belajarnya yang tidak kunjung terpenuhi. Dari kemudian dari peristiwa yang telah disebutkan di atas (baca: setelah mengobati Pengeran Nuh Ibnu Manshur) Ibnu Sina diberi kebebasan untuk belajar di perpustakaan Kutub Khana. Dari sinilah ia dapat menguasai ilmu beberapa ilmu pengetahuan. Dilain pihak, Ibnu Sina pernah juga berguru kepada AlFarabiy ketika dia merasa kesulitan dalam memahami metafisika Aristoteles. ${ }^{17}$

Pada usia 22 tahun, ayahnya meninggal dunia, kemudian Ibnu Sina meninggalkan negeri Buhkara untuk menuju ke Jurjan dan dari sini Ibnu Sina pergi ke Chawarazam. Di Jurjan Ibnu Sina mengajar dan menulis, tetapi kekacauan politik, Ibnu Sina tidak lama tinggal di sana. Kemudian hidupnya berpindahpindah dari satu tempat ke tempat lain hingga sampai di Hamadan. Di tempat ini Ibnu Sina pernah diangkat jadi menteri meskipun Ibnu Sina pernah dipenjarakan beberapa bulan. Selanjutnya, ia berpindah lagi ke Isfahan, di bawah penguasa Ala Addaulah, Ibnu Sina disambut baik olehnya. Namun pada akhirnya Ibnu Sina kembali ke Hamadan, ketika Ala Addaulah merebut negeri Hamadan. Pada usia 58 tahun di tempat Ibnu Sina meninggal dunia. ${ }^{18}$

Selama hidupnya serta kehausannya dalam menimba ilmu, Ibnu Sina telah menghasilkan beberapa karya-karya masyhur yang kesemuanya 276 buah. ${ }^{19}$ Diantara karya-karya tersebut antara lain: As-Syifa (Tha Book Of Recovery Or The Book Of Remedy) yakni buku tentang penemuan, atau buku

\footnotetext{
${ }^{12}$ Zar Sirajuddin, Filsafat Islam: Filosof Dan Filsafatnya (Jakarta: PT RajaGrafindo Persada, 2004).

13 Abuddin Nata, "Pemikiran Para Tokoh Pendidikan Islam: Kajian Filsafat Pendidikan Islam" (Jakarta: RajaGrafindo Persada, 2000).

${ }^{14}$ Sirajuddin, Filsafat Islam: Filosof Dan Filsafatnya.

${ }^{15}$ Ahmad Mustofa, Filsafat Islam (Bandung: Pustaka Setia, 1997).

${ }^{16}$ Harun Nasution, Falsafat Dan Mistisisme Dalam Islam, Cet (Jakarta: Bulan Bintang, 1995).

${ }^{17}$ Sirajuddin, Filsafat Islam: Filosof Dan Filsafatnya.

${ }^{18}$ Sirajuddin.

19 Jalaluddin and Usman Said, Filsafat Pendidikan Islam: Konsep Dan Perkembangan Pemikirannya (Jakarta: PT RajaGrafindo Persada, 1999).
} 
tentang penyembuhan. Buku ini dikenal didalam bahasa Latin dengan nama Sanatio, atau Sufficienta. Seluruh buku ini terdiri dari 18 jilid, naskah selengkapnya sekarang tersimpan di Oxford University London. Mulai ditulis pada usia 22 tahun (1022M) dan berakhir pada tahun wafatnya (1037M). Isinya terbagai atas empat bagian, yaitu: pertama, logika termasuk didalamnya retorika dan syair meliputi dasar karangan Aristoteles tentang logika dengan dimasukkan segala materi dari penulis-penulis Yunani kemudiannya. Kedua, Fisika, termasuk psikologi, pertanian, dan hewan. Bagian-bagian fisika meliputi kosmologi, meteorologi, udara, waktu, kekosongan dan gambaran. Ketiga, matematika, bagian ini mengandung pandangan yang berpusat dari elemen-elemen euclid, garis besar dari almagetsnya ptolemy, dan ikhtisar-ikhtisar tentang aritmatika dan ilmu musik, dan keempat, ialah metafisika yang termasuk falsafah, pokok pikiran Ibnu Sina menggabungkan pendapat Aristoteles dengan elemenelemennya Neo Platonic dan menyusun dasar percobaan untuk menyesuaikan ide-ide Yunani dengan kepercayaan-kepercayaan; Nafat yaitu buku tentang ringkasan dari buku As-Syifa; Qanun, buku tentang ilmu kedokteran; Sadidiyya buku ilmu kedokteran; Al-Musiqa, buku mengenai musik; Al-Manthiq, diuntukkan buat Abul Hasan Sahli; Qamus El Arabi, terdiri atas 5 jilid; Danesh Nameh merupakan buku filsafat; Uyun Al-Hikmah juga buku mengenai filsafat; Mujis, Kabir Wa Saghir. Sebuha buku yang menerangkan tentang dasar-dasar ilmu logika secara lengkap; Hikmah El Masyriqiyyin, falsafah timur (Britannica Encyplopaedia); Al-Inshaf buku tentang keadilan sejati; Al-Hudud, buku yang berisikan istilah-istilah dan pengertian-pengertian yang dipakai di dalam ilmu filsafat; Al-Isyarat Wat Tanbiehat. Buku ini lebih membicarakan dalil-dalil dan peringatan-peringatan yang mengenai prinsip Ketuhanan dan keagamaan; dan al-Najah buku tentang kebahgiaan hidup. ${ }^{20}$

Ibnu Sina banyak mempelajri kitab dari karya Abi Abdillah Al-Natily yang berjudul Isagogi dan karya Eclides serta Al-Magisty. Pada waktu Ibnu Sina menerangkan isi buku-buku tersebut kepada gurunya Ibnu Sina menunjukkan kecerdasan yang mengagumkan, karena Ibnu Sina dapat mengungkapkan isinya secara jelas sesuai dengan rumus-rumus dan problematika yang ditulis dalam buku-buku tersebut, dimana gurunya sendiri tidak memahaminya. Ibnu Sina mendalami ilmu-ilmu alam dan teologi kemudian mempelajari ilmu kedokteran sehingga Ibnu Sina ahli dalam kedokteran dan diangkat menjadi supervisor. Ibnu Sina praktek sebagai dokter, mengobati orang sakittidak untuk mencari kekayaan tetapi ilmunya sekedar untuk digunakan alat untuk berkomunikasi dan berinteraksi dengan para dokter pada masa itu dan untuk memuaskan dorongan cintanya kepada ilmu kedokteran. Pada usia 16 tahun kemasyhurannya telah menyebar luas sampai kepada para ahli kedokteran lainnya sehingga ia tertarik mempelajari pengalaman berbagai macam teknik penyembuhan daripadanya. Memang ia mencurahkan seluruh waktunya untuk menelaah, membaca dan membahas serta menganalisa disamping meneliti dan melakukan pengkajian terhadap berbagai pendapat para ahli. ${ }^{21}$

Salah satu bentuk pemikiran dalam logika Ibnu Sina ialah masalah ilmu. Menurutnya ilmu itu ada dua macam yaitu tashawur dan tashdiq. Tashawur atau ilmu yang hanya tergambar dalam pikiran adalah ilmu pengetahuan pertama yang didapat tanpa senagaj yang tidak dapoat diterapkan apakah benar atau salah seperti pemahaman tentang hakikat manusia. Disisi lain, ilmu tashdiq atau ilmu yang dapat dibuktikan dengan indera ialah ilmu pengetahuan yang diperoleh melalui pengamatan yang dapat diterapkan benar dan salah seperti pengetahuan tentang adanya asal muasal. Kedua macam ilmu pengetahuan tersebut dapat dibagi lagi menjadi dua macam yang menjadi asal dan yang diperoleh dari asal. Tashawur yang diperoleh dari asal melalui had atau term yang berlaku melalui yang mirip dengan term. Sednagkan tashdiq diperoleh dari kias atau silogisme dan yang diperoleh melalui jalan lain yang serupa dengan kias. Had dan silogisme keduanya merupakan alat untuk mengungkapkan pengetahuna yang dahulunya belum diketahui. Kedua macam yakni term dan silogisme ada yang hakiki dan ada yang bukan hakiki namun kedua-duanya sangat diperlukan tetapi ada diantaranya yang salah yang tidak dapat dikatakan mirip dengan hakiki. Kalau hanya melalui fitrah manusia belum mampu membedakan antara macam-macam ilmu di atas kecuali mendapat petunjuk Allah SWt., Karen itu bagi orang yang bedrpikir

${ }^{20}$ Sirajuddin, Filsafat Islam: Filosof Dan Filsafatnya.

${ }^{21}$ Ali Al-Jumbulati, H M Arifin, and Abdul Futuh At-Tuwaanisi, Perbandingan Pendidikan Islam (PT Rineka Cipta, 1994). 
harus mempunyai kaidah berpikir agar terpelihara dari kesalahan dan inilah yang menjadi tujuan utama ilmu logika. 22

Ibnu Sina adalah orang yang kuat nikah, sehingga tenaganya dihabiskan untuk meuaskan nafsu syahwatnya dengan isteri-isterinya. Oleh karena itu, Ibnu Sina akhirnya mengalami lemah jasmani dan menderita berbagai penyakit. Pada waktu tinggal di Isfahan Ibnu Sina terkena penyakit berat yang menimbulkan suhu panas tinggi di tubuhnya. Pada suatu ketika penyakitnya mencapai titik optimal dan hal ini menyebabkan timbulnya bisul bernaha di bagian perutnya, maka makin beratlah penyakitnya. Penyakit ini timbul pada saat Ibnu Sina mengungsi bersama pembesar-pembesar pemerintah saat itu antara Hamadan dan Isfahan dan ketika Ibnu Sina pulang kembali ke Hamadan kesehatannya menurun dan Ibnu Sina tidak lagi berobat. Ibnu Sina berkata kepada dirinya sendiri, "orang yang merawat tubuhku tidak diperlukan lagi, karena saya tidak sakit membutuhkan lagi pengobatan, maka Ibnu Sina mandi dan bertobat kepada Allah SWT, serta menyedekahkan semua harta kekayaannya kepada fakir miskin, mejauhi perbuatan zalim kepada siapapun, memerdekakan hamba sahayanya, sisa hidupnya digunakan untuk membaca Al-Qur'an sehingga tiap hari dapat khatam Al-Qur'an sebanyak tiga kali". Aktivitas ini ia lakukan sampai datangnya ajal di Hamadan pada hari Jum'at bulan Ramadhan tahun 328H dalam usia 58 tahun dan dimakamkan di kota ini. ${ }^{23}$

\section{Pemikiran Ibnu Sina Mengenai Pendidikan: Dari Tujuan Hingga Guru}

\section{Tujuan Pendidikan}

Menurut Ibnu Sina bahwa tujuan pendidikan harus diarahkan pada pengembangan seluruh potensi yang dimiliki seseorang ke arah perkembangannya yang sempurna, yaitu perkembangan fisik, intelektual dan budi pekerti. Selain itu, tujuan pendidikan menurut Ibnu Sina harus diarahkan pada upaya mempersiapkan seseorang agar dapat hidup di masyarakat secara bersama dengan melakukan pekerjaan atau keahlian yang dipilihnya sesuai dengan bakat, kesiapan, kecenderugan dan potensi yang dimilikinya.

Khusus mengenai pendidikan yang bersifat jasmani, Ibnu Sina mengemukakan hendaknya tujuan pendidikan tidak melupakan pembinaan fisik dan segala sesuatu yang berkaitan dengannya seperti olah raga, makan, minum, tidur dan menjaga kebersihan. Melalui pendidikan jasmani atau olah raga, seorang peserta didik diarahkan agar terbina pertumbuhan dan cerdas otaknya. Sedangkan dengan pendidikan budi pekerti diharapkan peserta didik memiliki kebiasaan bersopan santun dalam pergaulan hidup sehari-hari. Sementara dengan pendidikan kesenian seorang peserta didik akan dapat mempertajam perasaannya dan meningkat daya khayalnya. Selain itu, Ibnu Sina juga mengemukakan tujuan pendidikan yang bersifat keterampilan yang ditujukan pada pendidikan bidang perkayuan, penyablonan, dan sebagainya, sehingga akan muncul tenaga-tenaga pekerja yang profesional yang mampu mengerjakan pekerjaan secara profesional. ${ }^{24}$

Jika beberapa pendapat yang dilontarkan oleh Ibnu Sina mengenai tujuan pendidikan tersebut kemudian dihubungkan antara yang satu dengan lainnya maka akan tampak bahwa Ibnu Sina memiliki pandangan tentang tujuan pendidikan yang bersifat hirarkis-struktural. Maksudnya, bahwa disamping memiliki pandangan yang bersifat universal sebagaimana disebutkan di atas pada bagian pertama, juga memiliki pendapat tentang tujuan pendidikan secara operasional yang bersifat kurikuler atau setiap bidang studi.

Ibnu Sina dalam pandangan di atas tersebut, searah dengan pandangannya mengenai insan kamil, yaitu manusia yang terbina seluruh potensi dirinya sendiri secara seimbang dan menyeluruh. Selanjutnya faktor situasi masyarakat yang sudah maju dan terspesialisasi pada masa Ibnu Sina hidup, sebagaimana dikemukakan di atas, juga memengaruhi rumusannya tentang tujuan pendidikan pada bidang keahlian sebagaimana disebutkan diatas. Dengan ciri-ciri ini terlihat dengan jelas pengaruh pandangan filsafatnya dan situasi sosial yang mengitarinya terhadap rumusan tujuan pendidikan yang dikemukakannya.

\footnotetext{
${ }^{22}$ Muhammad ibn'Abd al-Karim al-Shahrastani and Asywadie Syukur, Al-Milal Wa Al-Nihal: AliranAliran Teologi Dalam Sejarah Umat Manusia (Bina Ilmu, 2005).

${ }^{23}$ Al-Jumbulati, Arifin, and At-Tuwaanisi, Perbandingan Pendidikan Islam.

${ }^{24}$ Hasan Langgulung, Manusia Dan Pendidikan: Suatu Analisa Psikologi, Filsafat Dan Pendidikan (Al Husna Zikra, 1995).
} 
Selain itu, rumusan tujuan pendidin Ibnu Sina tersebut di atas juga tampka berpijak pada kenyataan yang dilaksanakannya sendiri, dan bukan hasil khayalan yang tidak mempunyai dasar pengalaman praktis. Dengan demikian dalam rumusan tujuan pendidikan yang dikemukakan Ibnu Sina itu sudah terkandung strategi yang mendasar mengenai dasar dan fungsi pendidikan yang dibeirkan kepada anak sebagai peserta didik. Fungdi tersebut tidak lain ialah harus dapat mengembangkan potensi dan bakat peserta didik yang terdapat pada dirinya secara optimal dan menyeluruh, juhga harus mampu menolong manusia agar eksis dalam melaksanakan fungsinya sebagai khalifah di masyarakat dengan keahlian yang dapat diandalkan. Dengan tujuan seperti in, Ibnu Sina tampak berusaha melaluka antisipasi dalam rangka membentuk manusia yang memiliki keahlian dan membendung lahirnya output pendidikan yang tidak mampu bekerja di tengah-tengah masyarakat yang berakibat pada timbulnya pengangguran. Tujuan pendidikan yang dikemukakan oleh Ibnu Sina itu tampak masih dapat diterapkan oleh seluruh bangsa yang menghendaki kemajuan. Selain itu, rumusan tujuan pendidikan oleh Ibnu Sina tampak mencerminkan sikapnay selain sebaai seorang pemikir, juga sebagai pekerja dan praktisi sebagaimana yang telah terdapat dalam dirinya. ${ }^{25}$

\section{Kurikulum}

Meskipun tidak secara formal Ibnu Sina menyebut term (istilah) kurikulum, namun demikian penulis dapat menggambarkan kurikulum dan materi ilmu pengetahuan yang harus diajarkan menurut Ibnu Sina. Materi pelajaran merupakan disiplin ilmu yang akan membantu peserta didik untuk mengisi ruang kosong dalam dirinya dan sekaligus membantu mengembangakan potensinya tersebut. Ibnu Sina membagi tingkatan materi ilmu pengetahuan yang harus dilalui anak didik harus berdasarkan tahap perkembangan dan usia pertumbuhan anak. ${ }^{26}$

Dalam hal kurikulum Ibnu Sina membeirkan batasan mengenai prinsip-prinsip pendidikan bahwa jangan memului pelajaran Al-Qur'an kepada anak melainkan setelah anak mencapai tingkat kematangan akal dan jasmaniah yang memungkinkan dapat menerima apa yang diajarkan. Mengitgrasikan antara pengajaran Al-Qur'an dengan hurufhijaiyah yaitu memperkuat pandangan pendidikan modern saat ini yaitu dengan metode campuran antara analitis dan strukturalistis dalam mengajar, membaca, dan menulis. Kemudian anak diajar agama pada waktu tingkat kematangan yang mantap dimana menurut adat kebiasaan hdiup keagamaan yang benar telah terbuka sampai dapat menyerap ke dalam jiwanya dan memengaruhi daya inderawi serta perasaannya. ${ }^{27}$

Kemudian dikaitkan dengan kurikulum yang secara sederhana istilah ini digunakan untuk menunjukan sejumlah mata pelajaran yang harus ditempuh untuk mencapai suatu gelar atau ijazah. Pengertian ini sejalan dengan pendapat Crow dan Crow yang mengatakan bahwa kurikulum adalah rancangan pengajaran yang isinya sejumlah mata pelajaran yang disusun secara sitemik yang diperlukan sebagai sarat untuk menyelesaikan suatu program pendidikan tertentu. Konsep Ibnu Sina tentang kurikulum didasarkan pada tingkat perkembangan usia peserta didik yaitu usia 3 sampai 5 tahun dan 6 sampai 14 tahun. ${ }^{28}$

Untuk usia 3 sampai 5 tahun misalnya, menurut Ibnu Sina perlu diberikan mata pelajaran oleh raga, budi pekerti, kebersihan, senia suara dan kesenian. Pelajaran olah raga atau gerak badan ialah untuk mengarahkan dalam rangkan membina kesempurnaan pertumbuhan fisik peserta didik dan fungsi organ tubuh secara optimal. Sedangkan pelajaran budi pekerti diarahkan untuk membekali peserta didik agar memiliki kebiasaan sopan santun dalam pergaulan hidup sehari-hari. Selanjutnya dengan pendidikan kebersihan diarahkan agar peserta didik memiliki kebiasaan mencintai kebersihan, dan dengan pendidikan seni suara dan kesenian diarahkan agar memiliki ketajaman peransaan dalam mencintai serta meningkatkan daya khayalnya.

Mengenai mata pelajaran oleh raga, Ibnu Sina memiliki pandangan yang banyak memengaruhi oleh pandangan psikologisnya. Dalam hubungan ini Ibnu Sina menjelaskan ketentuan dalam berolah raga yang disesuaikan dengan tingkat perkembangan usia peserta didik serta bakat yang dimilikinya.

${ }^{25}$ Nata, "Pemikiran Para Tokoh Pendidikan Islam: Kajian Filsafat Pendidikan Islam."

26 Putra, "Pemikiran Filosofis Pendidikan Ibnu Sina Dan Implikasinya Pada Pendidikan Islam Kontemporer."

27 Al-Jumbulati, Arifin, and At-Tuwaanisi, Perbandingan Pendidikan Islam.

${ }^{28}$ Nata, "Pemikiran Para Tokoh Pendidikan Islam: Kajian Filsafat Pendidikan Islam." 
Dengan cara demikian dapat diketahui secara pasti mana saja diantara peserta didik yang perlu diberikan pendidikan olah raga sekedarnya saja, dan mana peserta didik yang pelru dilatih berolah raga lebih banyak kagi. Ibnu Sina lebih lenjut memperinci tentang mana saja di natara olah raga yang memerlukan dukungan fisik yang kuat serta keahlian dan mana saja olah raga yang tergolong ringan, cepat, lambat, memerlukan peralatan dan sebagainya. Menurutnyas semua jenis olah raga ini disesuakan dengan kebutuhan bagi kehidupan peserta didik.

Dari sekian banyak olah raga, menurut Ibnu Sina yang perlu dimasukkan kedalam kurkulum atau rancangan mata pelajaran adalah olah raga adu keuatana, gulat, meloncat, jalan cepat, memanah, berjalan dengan satu kaki dan mengendarai unta. Disamping itu, Ibnu Sina membahas pula tentang olah raga yang berlaku umum dan olah raga yang berlaku khusus, serta olah raga yang berlaku untuk semua jenis kelamin dan usia. Mengenai pelajaran kebersihan Ibnu Sina mengemukakan bahwa pelajaran hidup bersih dimulai dari sejak anak banung tidur, ketika hendak makan, sampai ketika hendak tidur kemblai. Dengan cara demikian, dapat diketahui mana saja anak yang mampu menerapkan hidup sehat dan mana saja yang bernampilan kotor dan kurang sehat. ${ }^{29}$

Selanjutnya kurikulum untuk anak usia 6 sampai 14 tahun menurut Ibnu Sina adalah mencakup mata pelajaran membaca, menghafal Al-Qur'an, pelajaran agama, pelajaran syair, dan pelajaran olah raga. Pelajaran membaca dan menghafal Al-Qur'an menurut Ibnu Sina berguna disamping untuk mendukung pelaksanaan ibadah yang memerlukan bacaan ayat-ayat suci Al-Qur'an, juga untuk mendukung keberhasilan dalam mempelajari agama islam seperti pelajaran tafsir, fikih, tauhid, dan pelajaran agama lainnya yang sumber utamanya adalah Al-Qur'an. Selain itu, pelajaran membaca dan menhafal Al-Qur'an juga mendukung keberhasilan dalam mempelajari bahasa Arab, karena dengan menguasai Al-Qur'an berarti ia telah menguasai ribuan kosakata bahasa Arab atau bahasa Al-Qur'an. Dengan demikian penetapan pelajaran membaca Al-Qur'an tampka bersifat strategis dan mendasar, baik dilihat dari segi pembinaan sebagai pribadi muslim, maupun dari segi pembentukan ilmuwan muslim, sebagaimana yang diperlihatkan oleh Ibnu Sina sendiri.

Kemudian daripada itu, kurikulum untuk usia 14 tahun mata pelajaran diberikan kepada peserta didik sesuai dengan bakat dan minatnya. Sehingga memerlukan pertimbangan dan kesiapan peserta didik. Artinya, kesiapan peserta didik untuk menerima mata pelajaran dengan baik. Ibnu Sina menganjurkan kepada para pendidik agar memilihkan jenis mata pelajaran yang berkaitan dengan keahlian tertentu yang dapat dikembangkan lebih lanjut oleh peserta didik. Di antara mata pelajaran tersebut dibagi ke dalam mata pelajaran yang bersifat teoritis dan praktis. Mata pelajaran yang bersifat teoritis antara lain ilmu tentang materi dan bentuk, gerak dan perubahan, wujud dan kehancuran, tumbuh-tumbuhan, hewan, kedokteran, astrologi, kimia, yang secara keseluruhan teegolong ilmu-ilmu fisika.

Selanjutnya ilmu tentang ruang, bayang dan gerak, memikul beban, timbangan, pandangan dan cermin serta ilmu memindahkan air yang secara keseluruhan tergolong ilmu matematika. Terdapat pula ilmu tentang cara turunnya wahyu, hakikat jiwa pembawa wahyu, mukjizat, berita gaib, ilham, dan ilmu tentang kekekalan ruh setelah berpisah dengan badan yang secara keseluruhan disebut ilmu ketuhanan. Mata pelajaran yang berisfat praktis adalah ilmu akhlak yang menjadi kajian yakni cara-cara pengurusan tingkah laku seseorang, ilmu pengurusan rumah tangga, yaitu ilmu yang mengkaji hubungan antara suami dan istri, anak-anak, pengaturan keuangan dalam kehidupan rumah tangga serta ilmu politik yang mengkaji tentang bagaimana hubungan antara rakyat dan pemerintah, kota dengan kota, bangsa dan bangsa. dalam ilmu bersifat praktis atau terapan, Ibnu Sina memasukkan pula ilmu tentang cara menjual dagangan, membatik, dan menenun. ${ }^{30}$

Dalam membahas ilmu-ilmu yang bersifat praktis, Ibnu Sina mengaitkannya dengan berbagai tugas dan pekerjaan yang ada dalam didalam kehidupan rumah tangga, masyarakat dan dunia pekerjaan atau profesi. Dengan ilmu yanfg bersifat praktis ini seseorang dapat dibantu dalam usaha mencari rezeki guna mewujudkan kesejahteraan hidupnya. Uraian tersebut di atas, tampak konsep kurikulum yang ditawarkan Ibnu Sina memiliki tiga ciri. Tiga tersebut yaitu pertama, konsep kurikulum Ibnu Sina tidak hanya terbatas pada sekedar menyusun sejumlah mata pelajaran, melainkan juga disertai dengan penjelasan tentang tujuan dari mata pelajaran dan kapan mata pelajaran itu harus diajarkan. Selain itu

\footnotetext{
${ }^{29}$ Nata.

${ }^{30}$ Nata.
} 
Ibnu Sina juga sangat mempertimbangkan aspek psikologis, yakni minat dan bakat para peserta didik dalam menentukan keahlian yang akan dipilihnya. Dengan cara demikian seorang peserta didik akan merasa senang atau tidak dipaksa dalam mempelajari suati ilmu atau keahlian tertentu.

Kedua, bahwa strategi penyusunan kurikulum yang ditawarkan Ibnu Sina juga didasarkan pada pemikiran yang bersifat pragmatis fungsional, yakni dengan melihat segi kegunaan ilmu dan keterampilan yang dipelajari dengan tuntutan masyarakat, atau berorientasi pada pasar (marketing oriented). Dengan cara demikian, setiap lulusan pendidikan akan siap difungsikan dalam berbagai lapangan pekerjaan yang ada di masyarakat.

Ketiga, strategi pembentukan kurikulum Ibnu Sina sangat dipengaruhi oleh pengalaman yang terdapat dalam dirinya. Pengalaman pribadinya dalam mempelajari berbagai macam ilmu dan keterampilan ia coba tuangkan dalam konsep kurikulumnya. Dengan kata lain, ia menghendaki agar setiap orang yang mempelajari berbagai ilmu dan keahlian menempuh cara sebagaimana ia tempuh. Dengan melihat ciri-ciri tersebut dapat dikatakan bahwa konsep kurikulum Ibnu Sina telah memenuhi persyaratan penyusunan kurikulum yang dikehendaki oleh masyarakat modern saat ini. Konsep kurikulum untuk anak usia 3 sampai 5 tahun mislanya tampak masih cocok untuk diterpakan di masa sekarang seperti pada kurikulum taman kanak-kanak.

\section{Metode Pembelajaran}

Konsep metode pembelajaran Ibnu Sina terdiri atas metode talqin, demonstrasi, pembiasaan dan teladan, diskusi, magang, dan penugasan metode dera dan hukuman. ${ }^{31}$ Metode talqin; Metode talqin perlu digunakan dalam mengajarkan membaca al-Qur'an, mulai de $\neg$ ngan cara memperdengarkan bacaan al-Qur'an kepada anak di-ndik, sebagian demi sebagian. Setelah itu anak tersebut disuruh mendengarkan dan mengulangi bacaan tersebut perlahan-lahan dan dilakukan berulang-ulang, hingga akhirnya ia hafal. Metode talqin ini menurut Ibn Sina dapat pula ditempuh dengan cara seorang pendidik meminta bantuan kepada para peserta didiknya yang sudah agak pandai untuk membimbing teman-temannya yang masih tertinggal. Cara seperti ini dalam ilmu pendidikan modern dikenal dengan nama tutor sebaya, sebagaimana dikenal dalam pengajaran dengan modul.

Metode demonstrasi; menurut Ibn Sina, metode demonstrasi dapat digunakan dalam pembelajaran yang bersifat praktik, seperti cara mengajar menulis. Menurutnya jika seorang pendidik akan mempergunakan metode tersebut, maka terlebih dahulu ia mencontohkan tulisan huruf hijaiyah di hadapan peserta didik. Setelah itu barulah menyuruh para peserta didik untuk mendengarkan ucapan huruf-huruf hijaiyah sesuai dengan makh-rajnya dan dilanjutkan dengan mendemonstrasikan cara menulisnya.

Metode pembiasaan dan keteladanan; Ibn Sina berpendapat bahwa pembiasaan adalah termasuk salah satu metode pengajaran yang paling efektif, khususnya dalam mengajarkan akhlak. Cara tersebut secara umum dilakukan dengan pembiasaan dan teladan yang disesuaikan dengan perkembangan jiwa si anak. Ia mengakui adanya pengaruh "mengikuti atau meniru" atau contoh tauladan baik dalam proses pendidikan di kalangan anak pada usia dini terhadap kehidupan mereka, karena secara tabi'iyah anak mempunyai kecenderungan untuk mengikuti dan meniru (mencontoh) segala yang ia lihat dan ia rasakann serta yang didengarnya. Oleh karena itu, dalam pergaluan pun, anak diharapkan berinteraksi dengan anak-anak yang berakhlak baik pula.

Metode diskusi; metode ini dapat dilakukan dengan cara penyajian pelajaran di mana siswa di hadapkan kepada suatu masalah yang dapat berupa pertanyaan yang bersifat problematis untuk dibahas dan dipecahkan bersama. Ibn Sina mempergunakan metode ini untuk mengajarkan pengetahuan yang bersifat rasional dan teoretis. Pengetahuan model ini pada masa Ibn Sina berkembang pesat. Jika pengetahuan tersebut diajarkan dengan metode ceramah, maka para siswa akan tertinggal jauh dari perkembangan ilmu pengetahuan tersebut.

Metode magang; Ibn Sina telah menggunakan metode ini dalam kegiatan pengajaran yang dilakukannya. Para peserta didik Ibn Sina yang mempelajari ilmu kedokteran dianjurkan agar menggabungkan teori dan praktek. Yaitu satu hari di ruang kelas untuk mempelajari teori dan hari berikutnya mempraktek-kan teori tersebut di rumah sakit atau balai kesehatan. Metode ini akan menimbulkan manfaat ganda, yaitu di samping akan mempermahir siswa dalam suatu bidang ilmu, juga

${ }^{31}$ Al-Jumbulati, Arifin, and At-Tuwaanisi, Perbandingan Pendidikan Islam. 
akan mendatangkan keahlian dalam bekerja yang menghasilkan kesejahteraan secara ekonomis. Dalam hal ini, pendidik harus mempersiapkan peserta didiknya sebelum magang sehingga magang tersebut tidak merugikan pihak lain.

Metode penugasan; metode penugasan ini pernah dilakukan oleh Ibn Sina dengan menyusun sejumlah modul atau naskah kemudian menyampaikannya kepada para peserta didiknya untuk dipelajarinya. Cara ini antara lain ia lakukan kepada salah seorang peserta didiknya bernama Abu arRaihan al-Biruni dan Abi Husain Ahmad as-Suhaili. Dalam bahasa Arab, pengajaran dengan penugasan ini dikenal dengan istilah at-ta'lim bi al-marasil (pengajaran dengan mengirimkan sejumlah naskah atau modul).

Metode targhib dan tarhib; targhib atau dalam pendidikan modern dikenal istilah reward yang berarti ganjaran, hadiah, penghargaan atau imbalan dan merupakan salah satu alat pendidikan dan berbentuk reinforcement yang positif, sekaligus sebagai motivasi yang baik. Ibn Sina juga memberikan perhatian pada metode ini. Menurutnya, memberi dorongan, memuji dan sebainya yang sesuai dengan situasi yang ada kadangkala lebih berpengaruh dan lebih dapat mewujudkan tujuan dari pada hukuman, sebab pujian dan dorongan dapat menghapus perasaan salah, berdosa dan menyesal. Namun, dalam keadaan terpaksa, metode hukuman (tarhib) dapat dilakukan. Pemikiran Ibn Sina tentang hukuman ini: Jika terpaksa harus mendidik dengan hukuman, sebaiknya diberi peringatan dan ancaman lebih dulu. Jangan meninddak anak dengan kekerasan, tetapi dengan kehalusan hati, lalu diberi motivasi dan persuasi dan kadang-kadang dengan muka masam atau dengan cara agar ia kembali kepada perbuatan baik, atau kadang-kadang dipuji didorong keberaniannya untuk berbuat baik. Perbuatan demikian itu merupakan perilaku yang mendahului tindakan khusus. Tetapi jika sudah terpaksa memukul, cukuplah pukulan sekali yang menimbulkan rasa sakit, karena pukulan yang cukup banyak menyebabkan anak merasa ringan, dan memandang hukuman itu sebagai suatu yang remeh. menghukum dengan pukulan dilakukan setelah diberi peringatan keras (ultimatum) dan menjadikan sebagai alat penolong untuk menimbulkan pengaruh yang positif dalam jiwa anak sebagai peserta didik.

Dari beberapa metode yang diuraikan di atas, menunjukkan bahwa Ibn Sina memberikan perhatian yang serius terhadap pendidikan. Paling tidak ada empat karakteristik metode yang ditawarkan oleh Ibn Sina, yaitu: pertama, pemilihan dan penerapan metode harus disesuaikan dengan karakteristik materi pelajaran. Kedua, metode juga diterapkan dengan mempertimbangkan psikologis peserta didik, termasuk bakat dan minat anak. Ketiga, metode yang ditawarkan tidaklah kaku, akan tetapi dapat berubah sesuai dengan kondisi dan kebutuhan peserta didik dan keempat, ketepatan dalam memilih dan menerapkan metode sangat menentukan keberhasilan pembelajaran. Jadi konsep tersebut di atas jika direlevansikan dengan tuntutan zaman hingga saat ini ada saling ketergantungan dan masih tepat untuk diterapkan. Itu artinya Ibn Sina memang memahami konsep pendidikan baik secara teoritis maupun secara praktis sehingga pemikiran yang ia kemukakan tidak hanya berlaku pada masanya, melainkan jauh melampaui masa tersebut.

\section{Guru atau Pendidik}

Guru yang baik adalah pendidik yang cakap secara intelektual, akhlak dan professional. Konsep pendidik yang dimaksudkan oleh Ibnu Sina guru yang cakap adalah guru yang berakal cerdas, beragama, mengetahui cara mendidik akhlak, cakap dalam mendidik anak, berpenampilan tenang, jauh dari berolokolok dan main-main di hadapan muridnya, tidak bermuka masam, sopan, santun, bersih dan suci murni. ${ }^{32}$ Jika dilihat Ibnu Sina memiliki pemikiran dan konsep revolusioner. Ibnu Sina menyarankan guru harus memiliki kompetensi personal, professional, sosial, Emosional dan Spiritual seperti apa yang diamanatkan dalam Undang-undang Nomor 14 tahun 2005 tentang Guru dan Dosen. Kompetensi personal dapat dilihat dalam penjelasanya bahwa guru harus berpenampilan tenang, sopan santun jauh dari berolok-olok. Kompetensi professional dapat dilihat pada pendapatnya guru harus cerdas dan mengetahui cara mendidik akhlak, cakap dalam mendidik anak. Kompetensi emosional dan spiritual dapat dilihat dari pendapatnya bahwa guru harus bersih dan suci murni, beragama, dan berpenampilan tenang.

Guru memiliki peran amat penting dalam pendidikan. Ibn Sina pun menuliskan beberapa pemikirannya tentang konsep guru, terutama yang menyangkut tentang guru yang baik. Menurutnya,

${ }^{32}$ Nata, "Pemikiran Para Tokoh Pendidikan Islam: Kajian Filsafat Pendidikan Islam." 
guru yang baik adalah guru yang berakal cerdas, beragama, mengetahui cara mendidik akhlak, cakap dalam mendidik anak, berpenampilan tenang, jauh dari berolok-olok dan main-main di hadapan muridnya, tidak bermuka masam, sopan santun, bersih dan suci murni.

Kemudian Ibnu Sina juga menambahkan bahwa seorang guru itu sebaiknya dari kaum pria yang terhormat dan menonjol budi pekertinya, cerdas, teliti, sabar, telaten dalam membimbing anak-anak, adil, hemat dalam penggunaan waktu, gemar bergaul dengan anak-anak, tidak keras hati dan senantiasa menghias diri. Selain itu guru juga harus mengutamakan kepentingan ummat daripada kepentingan diri sendiri, menjauhkan diri dari meniru sifat raja dan orang-orang yang berakhlak rendah, mengetahui etika dalam majelis ilmu, sopan dan santun dalam berdebat, berdiskusi dan bergaul.

Ibnu Sina juga menekankan agar seorang guru tidak hanya mengajarkan dari segi teoritis saja kepada peserta didiknya, melainkan juga melatih segi keterampilan, merubah budi pekerti dan kebebasannya dalam berfikir. Ia juga menekankan adanya perhatian yang seimbang antara aspek penalaran (kognitif) yang diwujudkan dalam pelajaran bersifat pemahaman; aspek penghayatan (afektif) yang diwujudkan dalam pelajaran bersifat perasaan; dan aspek pengamalan (psikomotorik) yang diwujudkan dalam pelajaran praktek.

Rumusan di atas menunjukkan bahwa Ibn Sina menginginkan seorang guru memiliki kompetensi keilmuan yang bagus, berkepribadian mulia dan kharismatik sehingga dihormati dan menjadi idola bagi peserta didiknya. Hal ini penting, sebab jika guru tidak memiliki wawasan yang luas tentang materi pelajaran yang diasuhnya dan kurang memiliki kharismatik, tentulah peserta didik kurang menyukainya. Jika hal itu terjadi, maka ilmu akan sulit didapat, meskipun diketahui tetapi keberkahannya jelas berkurang.

\section{SIMPULAN DAN SARAN}

\section{Simpulan}

Dari uraian singkat di atas, setidaknya memberikan insipirasi bahwa Ibnu Sina atau Evicienna adalah merupakan salah satu tokoh yang memiliki kontribusi besar dalam khazanah keilmuan dalam Islam khususnya yang berkaitan dengan pendidikan Islam. Disamping itu, pemikiran Ibnu Sina mengenai pendidikan secara terstruktur dari tujuan, kurikulum, metode pembelajaran dan guru atau pendidik ialah faktron daripada unsur-usur determinan dalam pendidikan. Oleh karena itu, pemikiran Ibnu Sina dapat dijadikan acuan penting dalam memajukan dunia pendidikan.

Dalam pandangan lain, bahwa hasil pemikiran Ibnu Sina tidak lain merupakan pengalaman hidupnya dalam menemukan ilmu pengetahuan yang sangat luas kemudian dituangkan kedalam media tulis dan menjadi sumber primer ilmu pengetahuan pada masanya. Dalam kaitan ini, kajian yang telah dipaparkan adalah salah satu asumsi menggali sumber primer tersebut dari khazanah keilmuan Ibnu Sina.

Saran

Untuk para guru, konsep pendidikan Ibnu Sina menarik untuk diterapkan dalam proses pembelajaran di kelas. Untuk para peneliti, konsep pendidikan Ibnu Sina meanrik untuk dikembangkan. Kedepannya, bisa dilakukan penelitian terkait pengembangan model pembelajaran dengan konsep pendidikan Ibnu Sina.

\section{DAFTAR PUSTAKA}

Al-Jumbulati, Ali, H M Arifin, and Abdul Futuh At-Tuwaanisi. Perbandingan Pendidikan Islam. PT Rineka Cipta, 1994.

al-Shahrastani, Muhammad ibn'Abd al-Karim, and Asywadie Syukur. Al-Milal Wa Al-Nihal: AliranAliran Teologi Dalam Sejarah Umat Manusia. Bina Ilmu, 2005.

Amin Abdullah, Mohd. Falsafah Kalam Di Era Postmodernisme. Yogyakarta: Pustaka Pelajar, 1995.

Assegaf, Abdur Rahman. Filsafat Pendidikan Islam: Paradigma Baru Pendidikan Hadhari Berbasis Integratif-Interkonektif. Rajawali Pers, 2011.

Idris, Saifullah, and Z A Tabrani. "Realitas Konsep Pendidikan Humanisme Dalam Konteks Pendidikan Islam.” Jurnal Edukasi: Jurnal Bimbingan Konseling 3, no. 1 (2017): 96-113.

Jalaluddin, and Usman Said. Filsafat Pendidikan Islam: Konsep Dan Perkembangan Pemikirannya. Jakarta: PT RajaGrafindo Persada, 1999. 
Langgulung, Hasan. Manusia Dan Pendidikan: Suatu Analisa Psikologi, Filsafat Dan Pendidikan. Al Husna Zikra, 1995.

Mas' ud, Abdurrachman. Menggagas Format Pendidikan Nondikotomik:(Humanisme Religius Sebagai Paradigma Pendidikan Islam). Gama Media, 2002.

Mustofa, Ahmad. Filsafat Islam. Bandung: Pustaka Setia, 1997.

Nasution, Harun. Falsafat Dan Mistisisme Dalam Islam, Cet. Jakarta: Bulan Bintang, 1995.

. "Islam Ditinjau Dari Berbagai Aspeknya.” UI Press, Cetakan V, 1985.

Nata, Abuddin. "Pemikiran Para Tokoh Pendidikan Islam: Kajian Filsafat Pendidikan Islam.” Jakarta: RajaGrafindo Persada, 2000.

Putra, Aris Try Andreas. "Pemikiran Filosofis Pendidikan Ibnu Sina Dan Implikasinya Pada Pendidikan Islam Kontemporer.” LITERASI (Jurnal Ilmu Pendidikan) 6, no. 2 (2016): 191-201.

Sirajuddin, Zar. Filsafat Islam: Filosof Dan Filsafatnya. Jakarta: PT RajaGrafindo Persada, 2004.

Smith, Huston, and M Darrol Bryant. Essays on World Religion. Paragon House Publishers, 1992.

Susilo, Madyo Eko, and R B Kasihadi. Dasar-Dasar Pendidikan. Semarang: Effhar, 2001.

Yunus, Mahmud, and Muhammad Qasim Bakri. Al-Tarbiyah Wa Al-Ta'lim. Padang Panjang: Mathba'ah, 1942. 